\title{
TACC1 wt Allele
}

National Cancer Institute

\section{Source}

National Cancer Institute. TACC1 wt Allele. NCI Thesaurus. Code C54449.

Human TACC1 wild-type allele is located within 8p11 and is approximately $96 \mathrm{~kb}$ in length. This allele, which encodes transforming acidic coiled-coil-containing protein 1, plays a role in cell cycle regulation by promoting exit from the M phase. Overexpression of the TACC1 gene is associated with several types of cancer such as breast carcinomas. 